\title{
Changing University Students' Alternative Conceptions of Optics by Active Learning
}

\section{ZALKIDA HADŽIBEGOVIĆ ${ }^{* 1}$ AND JOSIP SLIŠKO ${ }^{2}$}

$\approx$ Active learning is individual and group participation in effective activities such as in-class observing, writing, experimenting, discussion, solving problems, and talking about to-be-learned topics. Some instructors believe that active learning is impossible, or at least extremely difficult to achieve in large lecture sessions. Nevertheless, the truly impressive implementation results of the SCALE-UP learning environment suggest that such beliefs are false (Beichner et al., 2000). In this study, we present a design of an active learning environment with positive effect on students. The design is based on the following elements: (1) helping students to learn from interactive lecture experiment; (2) guiding students to use justified explanation and prediction after observing and exploring a phenomenon; (3) developing a conceptual question sequence designed for use in an interactive lecture with students answering questions in worksheets by writing and drawing; (4) evaluating students' conceptual change and gains by questions related to light reflection, refraction, and image formation in an exam held a week after the active learning session. Data were collected from 95 science freshmen with different secondary school backgrounds. They participated in geometrical optics classes organized for collecting research results during and after only one active learning session. The results have showed that around $60 \%$ of the students changed their initial alternative conceptions of vision and of image formation. It was also found that a large group of university students is likely to be engaged in active learning, shifting from a passive role they usually play during teacher's lectures.

Keywords: Active learning; Alternative conceptions; Geometrical optics; Large-enrolment; University students

$1 \quad{ }^{*}$ Corresponding Author. University of Sarajevo, Faculty of Science, Bosnia and Hercegovina; zalkidah@yahoo.com

2 Facultad de Ciencias Fisico Matematicas, Benemerita Universidad Autonoma de Puebla, Mexico; jslisko@fcfm.buap.mx 


\section{Spreminjanje alternativnih pojmovanj v optiki $\mathrm{z}$ aktivnim učenjem pri študentih}

ZALKIDA HADŽIBEgović* IN Josip SLIŠKo

$\propto$ Aktivno učenje je individualno in skupinsko sodelovanje pri aktivnostih, kot so: opazovanje v razredu, pisanje, eksperimentiranje, diskutiranje, reševanje problemov in pogovarjanje o temah, ki naj bi se jih naučili. Nekateri predavatelji menijo, da je aktivno učenje pri predavanjih $\mathrm{z}$ veliko udeležbo nemogoče ali pa vsaj zelo težavno. Vendar pa izsledki vpeljave učnega okolja SCALE-UP govorijo proti takim prepričanjem (Beichner et al., 2000). V študiji bova predstavila model okolja za aktivno učenje s pozitivnim učinkom na študente. Model temelji na naslednjih postavkah: 1) učenje študentov s pomočjo eksperimentiranja v sklopu predavanj; 2) usmerjanje študentov pri pravilnih razlagah in napovedih po opazovanju in raziskovanju pojava; 3) priprava niza konceptualnih vprašanj za uporabo v sklopu interaktivnega predavanja, pri katerem študentje pisno in s skiciranjem odgovarjajo na vprašanja na delovnem listu; 4) evalvacija konceptualnih sprememb in nadgradenj pri izpitnih vprašanjih o odboju in lomu svetlobe ter o nastanku slike, ki so bile izvedene en teden po koncu učnega posega. Vzorec je zajemal 95 študentov prvega letnika naravoslovnih študijskih smeri z različno predhodno srednješolsko izobrazbo. Študentje so sodelovali pri urah aktivnega učenja o geometrijski optiki, ki so bile izvedene enkrat - samo za namen študije. Izsledki kažejo, da je svojo prvotno predstavo o vidu in oblikovanju slike spremenilo okoli 60 odstotkov študentov. Ugotovitve kažejo tudi, da je aktivno učenje povsem mogoče vpeljati v veliko skupino študentov in spremeniti običajno pasivno vlogo študentov med tradicionalnimi oblikami predavanj.

Ključne besede: aktivno učenje, alternativni koncepti, geometrična optika, množični vpis, univerzitetni študentje 


\section{Introduction}

During their education, science students are expected to develop critical thinking and learning skills to address novel problem-solving and team-workbased issues that will be essential in their future careers and lives. Teachers have a crucial role in leading students to achieve such high level of work competencies in a knowledge-based economy and society. The main aim of this paper is to describe an in-class learning sequence for the active learning of physics designed for a large group of science students. Based on experience and education research in general, science students finishing the first cycle of the Bologna model of study do not have enough knowledge to cope with problem solving in real life. It is well known that students' 'inert knowledge' is a key problem in modern education (Whitehead, 1959). Both students and teachers should learn techniques for the practical use of their knowledge in order to understand the underlying concepts in a particular field of study. This teaching paradigm shift should be accepted by both students' and teachers, and not only at a level of accepting declarations and documents in the Bologna Process as a main process in higher education in Europe. Grabiner and Dunlap (1995) propose a definition of learning as 'cognitive, involving processes of critical information assessment and the constant creation and evolution of knowledge structures' for helping educators and students to reach their learning new goals. There are many possibilities for introducing active learning environments, such as inquiry learning around realistic problems, learning through practice and application, interactive-learning environments, information-rich learning environments, etc. Active learning in science means a shift in the traditional teaching methodology to enable students to take an active role as investigators, problem solvers and to change a role of teachers to be students' guides and facilitators instead of knowledge presenters (Adams et al., 1988).

Meltzer and Thornton (2012, p. 478), when discussing the active learning of physics as 'instruction involving students in their own learning more deeply and more intensely than does traditional instruction, particularly during class time', described in their 'Resource Letter' the instructional methods of many research-based active-learning instructional modules in physics originating after the 1970s. Most science education researchers consider active learning methods to be an important opportunity to give students a basic conceptual understanding and problem-solving abilities developing in an active learning environment (different in-class activities, observational experiments, hands-on activities, computer simulations, mathematical modelling, etc.). Michael Prince (2004) gave a simple definition of active learning as any instructional method 
that engages students to shift from a passive to an active role in the learning environment (classroom or other place where students learn). Unquestionably, the active learning of physics means to change traditional lectures or lab work and the level of passively receiving information from teachers or cook-bookstyle lab manuals.

In traditional lectures, students are not encouraged to move beyond the memorization of the information delivered by instructors, and communication of information and concepts are not student-centred. In the student-centred teaching-learning process, instructors are supposed to help students to analyse, synthesize, and evaluate information by being engaged in activities that prepare them to reflect upon ideas and upon how they are using those ideas.

In this study, a design of an active learning sequence in the traditional teaching-learning environment (the amphitheatre) is presented. It is based on the following elements:

1) having students engaged in classroom activities;

2) urging students to think about the presented information;

3) helping students to evaluate the information transfer through PredictionObservation-Explanation activities (White \& Gunstone, 1991);

4) engaging students to discuss the topics with classmates and instructor or through the worksheet writings;

5) helping students to change their alternative conceptions by their active engagement.

Two research questions (RQ) are:

RQ1: What are the students' possibilities and challenges in an active learning environment?

RQ2: What are students' conceptual changes after an active learning sequence of a geometrical optics phenomenon?

To obtain answers to the research questions, it was necessary to evaluate students' understanding of geometrical optics processes (light reflection, light refraction and image formation) by examining collected student responses received during an in-class experiment, through worksheet writings and drawings, as well as through exam evaluation of active learning sequence content.

\section{Method}

The data presented here are part of a pilot study of an implementation of active learning methods and materials with science students at Sarajevo 
University in Bosnia and Herzegovina. Since there is no empirical investigation of the students' conceptual understanding of the optical phenomena in existing physics courses at the University of Sarajevo, the main aim was to find out how a group of science students understood basic concepts of geometrical optics before, during and after a 90-minute active learning sequence (ALS).

\section{Participants}

Data were collected from 95 students ( $88 \%$ of female freshmen) who were enrolled in the first year of a science programme. They started university education with different secondary school backgrounds in physics. Around half of enrolled freshmen (52\%) had previously finished a four-year high school (a so-called gymnasium) where they learned physics during only in the first and second years. Other students have studied physics in different high schools (mostly secondary medical school, and classic high school) for four years (41\%), for only one year (5\%), and there was also a group of students who never studied secondary school physics (2\%). The research was carried out in the spring semester of 2011.

Every academic year, a large group of students (around 130-150 freshmen) take the course General Physics II in the spring semester (9o minutes per week). Around 100 of them attend each meeting with their instructor. Before the ALS implementation, students were taught the basic topics of geometrical optics within four school hours (each 45 minutes). Firstly, the instructor (Z. H.) attempted to refresh their basic knowledge in geometrical optics delivered to them four years ago (in the last grade of elementary school) or two years ago (during their secondary schooling). Secondly, through their regular physics course, science freshmen were taught the themes of geometrical optics as calculus-based course content. The students showed weakness in applying their mathematical knowledge to derive the geometrical optics laws at a higher mathematical level compared with those who studied the topic in the secondary schools. According to the instructor's experience, the students did not have sufficiently developed conceptual understanding of geometrical optics content. They mainly attended their physics classes as passive listeners. The university physics course usually is a learning environment in an amphitheatre as a classroom for a large group of students (between 100 and 150 students). These reasons motivated this physics course instructor (Z. H.) to explore opportunities to increase not only the students' active engagement and interest for deeper learning of geometrical optics but also to achieve a greater number of students passing exams. To meet such goals, an ALS was chosen to make a 
lecture change in the amphitheatre as a learning environment in the university physics course (Figure 1).

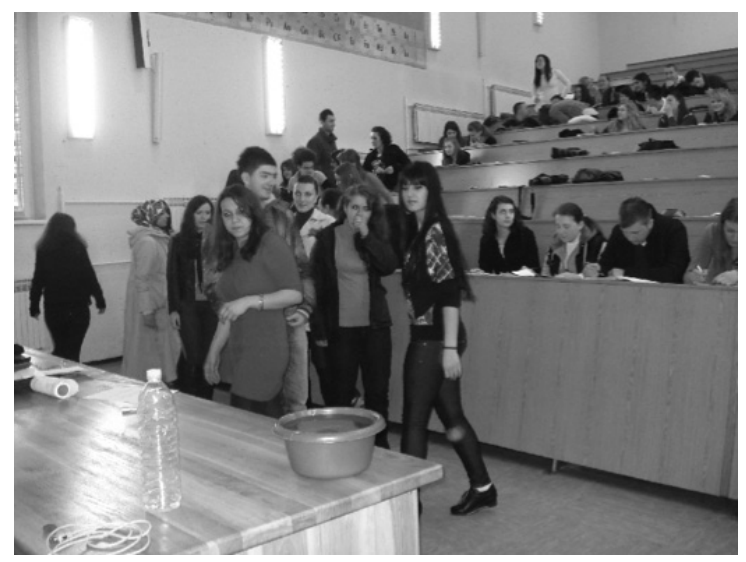

Figure 1. An ALS organized in the amphitheatre as students' learning environment.

\section{ALS context}

An ALS of geometrical optics was implemented to achieve two main learning goals:

1) to enable students to learn geometrical optics actively by predicting-observing-explaining different aspects of an experiment with a metal sphere (MS) placed in a plastic bowl (without and with water);

2) to evaluate students' gained knowledge after ALS implementation within a regular midterm physics course examination.

\section{Experiment setting and ALS protocol}

A heavy metal sphere (MS), illuminated by daylight, was placed at the bottom of an opaque plastic bowl (Figure 2). The same idea for an optics demonstration experiment can be seen in many physics textbooks with a coin in the bowl, with and without water (Mandell, 1968). For this research, a big MS was more suitable than a small coin.

In the first part of the ALS experiment, the MS was at the bottom of the empty bowl and students had the task of describing the image formation of the MS verbally and by drawing it. In the second part of the experiment, the Predict-Observe-Explain (POE, White \& Gunstone, 1991) teaching technique 
was implemented. Students were required to present their responses in both parts of the experiment via in-class worksheet writings.
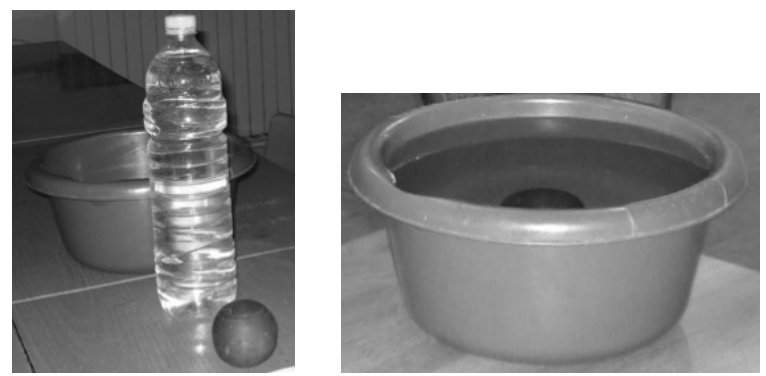

Figure 2. A plastic bowl, bottled water and a metal sphere as a set of experimental material used in the ALS experiment.

A worksheet (WS) was created and applied in the ALS of geometrical optics, according to the POE protocol. The worksheet questions were addressing students' conceptual understanding of light source role, the role of observer's eye, light reflecting from the metal sphere, light refracting in the air-water and water-air systems, image formation and image nature.

Students' responses about the vision model (VM) were considered according to the created coding scheme, recognizing three kinds of students' responses:

1) SVM: scientific vision model;

2) AVM: alternative vision model;

3) NCVM: without the concept of vision.

SVM states that light rays travel from a light source to the MS as a subject of vision, its reflection on the MS (Figure 3a) or its refraction-reflection-refraction in the air-water-MS-water-air system (Figure $3 \mathrm{~b}$ ) and after which light rays travel into the observer's eyes. In this model, at least two close rays have to appear in the students' drawings using the light-ray model. Without water, the apparent position of the MS coincides with its real position in the bowl. With water added, the apparent position of the MS does not coincide with its real position, but appears higher (Figure 3). 


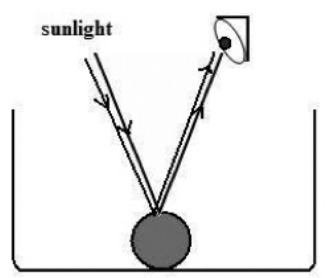

a)

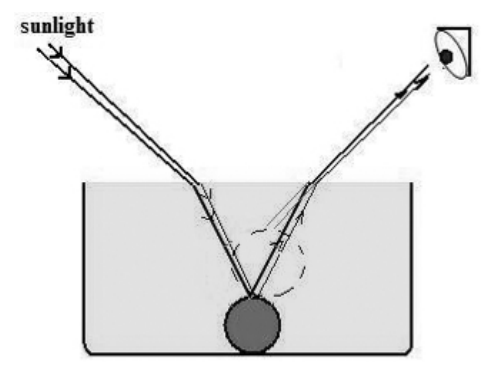

b)

Figure 3. Examples of drawings that represent concepts of the SVM: (a) for an MS placed in the empty bowl, and (b) an MS placed in a bowl with water.

It is important to stress that incorrect drawings of the apparent depth of an object in water are frequently found in physics textbooks (Nassar, 1994). For example, even Nobel Prize Winner Sheldon L. Glashow has presented a completely erroneous drawing and calculation of the image position of a diamond ring resting at the bottom of a swimming pool. Based on them, he says: 'The ring appears to be much further from the edge than it really is' (Glashow, 1994).

Thanks to superficial treatment of image formation in physics textbooks (and, very likely, in classroom teaching), it is not surprising that students reveal poor understanding of how the image of an underwater object should be found using ray model of light propagation (Kaewkhong et al., 2010).

AVM is an alternative vision model with two bodies included along travelling paths of light rays (light source-MS; eye-MS; MS-eye or MS-water, or combining some of these noted pairs as a light travel path).

NCVM consists of some nonphysical solving approaches or art works without any vision model used.

Both qualitative and quantitative data analyses are carried out. In the focus of qualitative data analysis were the students' drawings by which they indirectly presented their vision models. The quantitative analysis of students' worksheet responses was implemented using a scoring system related to the first and second parts of worksheet activities, presented in Appendix 1 and Appendix 2. The third part of the worksheet consists of an open-ended question about students' emotions and opinions related to their ALS experiences. The total number of worksheet grading points is six (6) points. Statistical data based on the results of the 95 students who responded to the worksheet questions in both the first and second parts of the worksheet activities were analysed.

In the regular General Physics II course midterm exam, organized a week after ALS implementation, students were asked to solve a task (question) that covered the ALS content. It was a way to evaluate students' conceptual 
knowledge of geometrical optics after the ALS. Here, it is necessary to note that the exam question was given after a 45-minute in-class explanation by the instructor about all correct answering in the ALS parts, held a week before their midterm exam. The exam question was given in the following form:

Based on the ALS of geometrical optics, your tasks are:

1) in the provided box you are supposed to attach your drawing presenting the image formation of the MS situated at the bottom of the empty bowl for a given observers' eye position to see the MS;

2) in the provided box you are supposed to attach your drawing presenting the image formation of the MS situated at the bottom of the water-filled bowl for a given observers' eye position to see the MS.

Correct answers to the exam question provide the maximum six points.

\section{Results and data analysis}

\section{The presence of Vision Models in students' responses}

Qualitative data analysis of student responses was carried out on a selection of students' drawings as visual representations of students' conceptual understanding of observed phenomenon and nature of the MS image formation.

There were $2.1 \%$ of students who gave no response at all. Among the remaining $97.9 \%$ of the students, there were a dominant number who showed their AVM (75.3\%), and only $7.2 \%$ of the students had vision models that were compatible with the SVM. Among 95 students, $8 \%$ used the NCVM. Students showed mostly the AVM option of the light rays travelling from the observer's eyes to the MS (61.8\%). The light rays' trajectory from the MS into the observer's eyes was found in $5.2 \%$ of the students' drawings. Here, it is necessary to emphasise that before the ALS was implemented in the Physics II lecture, many students studied geometrical optics at three levels of physics education (elementary school, secondary school and university).

Among 95 students, only two of them showed proper understanding of image formation when light reflects at the MS touching the bottom of empty bowl. However, there were no drawings showing students' understanding of the MS image nature if the MS was situated in the bowl with water. In an elementary school textbook previously used by students, there are correct figures showing two rays of light as a minimum number of rays entering an eye needed for image formation (Kulenović, 2006).

Since the distribution of points related to the coding scheme presented in Appendix 1 and Appendix 2 was not normal, scores were expressed by 
median value (2 points). Students' scores were divided into seven groups as presented in Table 1.

As shown in Table 1, there are 11 students without any points, whereas only four students who achieved five points, which is the maximum number of points. Especially pertinent is the fact that only a few students $(<20 \%)$ gave their explanations for each of WS task parts.

Table 1. The students' point distribution related to the scoring scheme.

\begin{tabular}{lcc}
\hline Category & Number of students N, (\%) & Median \\
\hline 6 points & 0 & 2 \\
5 points & $4(5)$ & \\
4 points & 0 & \\
3 points & $25(26)$ \\
2 points & $27(28)$ \\
1 point & $28(29)$ \\
0 points & $11(12)$ \\
\hline
\end{tabular}

The situation is relatively better in the case of distribution of responses related to the prediction parts. In this case, more than $60 \%$ of the students had correct predictions in both types of the ALS prediction phases (Table 2). But students' difficulties remain the same when they need to provide an accurate justification for their predictions and to demonstrate that they understand what the nature of the formed image is.

Table 2. Students' rates of correct predictions, explanations and image formation.

\begin{tabular}{lccc}
\hline Item & $\begin{array}{c}\text { Rate of correct } \\
\text { predictions (\%) }\end{array}$ & $\begin{array}{c}\text { Rate of correct } \\
\text { explanations (\%) }\end{array}$ & $\begin{array}{c}\text { Correct image } \\
\text { formation (\%) }\end{array}$ \\
\hline Prediction 1 & 62 & 18 & 2 \\
Prediction 2 & 63 & 11 & 0 \\
\hline
\end{tabular}

\section{Vision Model application in ALS based exam answers}

Students showed marked improvement when solving an exam task based on the implemented ALS. They showed vision models that were not quite the SVM, but which were much closer to it. However, they still revealed weakness in the presentation of image formation if the MS was at the bottom of the bowl with water. 
Most of the students, among the 95 who were ALS participants, illustrated their responses using the SVM. Still, some students had their alternative conceptions revealed, and there were around $10 \%$ of students without any vision model (Table 3 ). Around seventy percent of students successfully solved the tasks, presenting their drawings of image formation. Table 3 shows that among such a significant number of students, there were three SVM categories presented for both phenomena reflection and refraction of light rays. Three SVM usages are found:

SVM1: VM as the SVM described above;

SVM2: VM in the frame of the SVM but with one light ray presented in each travelling path;

SVM3: VM in the frame of SVM but with one light ray presented only after its reflection on the MS and travelling to the observer's eye.

The number of students with the alternative conceptions of vision and image formation markedly decreased. A total of $16 \%$ of the students continued to show their alternative models (Table 3 ). Two such alternative models without any information about light source are:

AVM1: light rays travel from the observer's eyes to the MS; AVM2: light rays travel from the MS into the observer's eyes.

A significant number of students (11.6\%) was without SVM/AVM or their task responses. A possible reason for such student's passive learning role could be explained by a possible relation toward self-irresponsibility to the study physics course content leaving it for their next (i.e. repeated) physics course.

Table 3. Students' responses of Vision Models used.

\begin{tabular}{lll}
\hline Vision Model & $\begin{array}{l}\text { Rate of students' } \\
\text { responses for ray } \\
\text { reflection (\%) }\end{array}$ & $\begin{array}{l}\text { Rate of students' } \\
\text { responses for ray } \\
\text { refraction (\%) }\end{array}$ \\
\hline SVM1 & 45 & 42 \\
SVM2 & 26 & 24 \\
SVM3 & 3 & 5 \\
AVM1 & 12 & 8 \\
AVM2 & 3 & 2 \\
NCVM & 9 & 16 \\
NR & 2 & 3 \\
\hline
\end{tabular}




\section{Students' conceptual change}

Students' responses were also analysed in order to determine specific alternative conceptions or difficulties based on pre-exam (ALS activities) and exam evaluation of their conceptual understanding of geometrical optic phenomena and image formation. The results (Table 3), compared with results presented above, show that positive conceptual changes occurred in students' minds regarding understanding of how a light ray travels and its image formation. However, a weak change occurred related to the nature of image as a real image (case of reflected light by the MS) or a virtual image (case of refracted/ reflected light by air-water-MS-water-air system). Around 30\% of the students correctly presented image formation and its nature by the reflection of light at the MS. Only $6 \%$ of students showed a virtual image of the MS after its formation in the observer's eye looking at the MS in water. Additionally, according to the drawings of the MS seen in water, it was possible to see whether conceptual change was retained or not.

By comparing students' alternative conceptions in exam responses, progress toward SVM was found, but still with a low improvement of understanding the MS image formation. Differences between the exam point scores and ALS scores were also significantly changed in a positive direction. A new dominant group of students was a group who has achieved the exam points between four and six points.

An example of student's drawings with a progress of understanding is presented in Figure 4, showing the light ray paths. Here, there is evidence of how this student changed his AVM (Figure 4a) to a vision model closer to the SVM (Figure $4 \mathrm{~b}$ ), but his understanding is not on the conceptual change path. The left sketch in Figure $4 \mathrm{~b}$ shows a student's answer about MS image formation if it is placed in the empty bowl. He used only one light ray as an incoming ray, but two light rays are presented as its reflected rays without a strict eye position. The right sketch is a student's answer about light travelling if the MS is placed in the bowl with water. It is presented as an impossible situation for image formation in the eye of the observer. One light ray after its first refraction and its reflection on the MS has a correct light path, but after second refraction it is presented as a refracted light ray that is stopped by the bowl's wall that is not seen by an observer. 


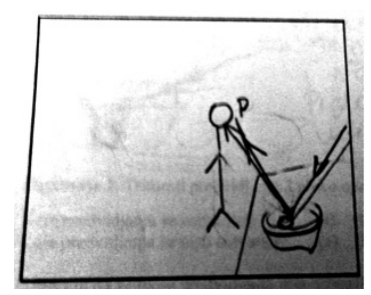

a)
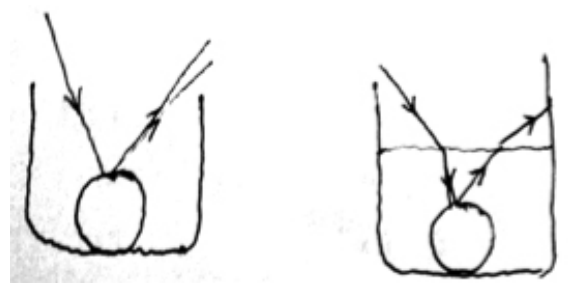

b)

Figure 4. An example of conceptual understanding progress achieved after the ALS. (a) Student \#1 AVM scheme in the ALS worksheet. There are two light rays as incoming and reflecting rays, but only one reflecting ray enters in the eye of the observer. Other pair of rays is incorrectly presented. (b) Student \#1 exam responses.

Student \#2 achieved a small change of his AVM, shown in Figure 5a, to a new vision model presented with a better understanding of the correct light path as shown in Figure 5b.

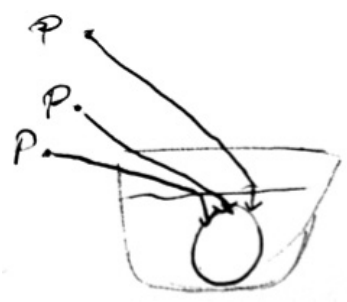

a)

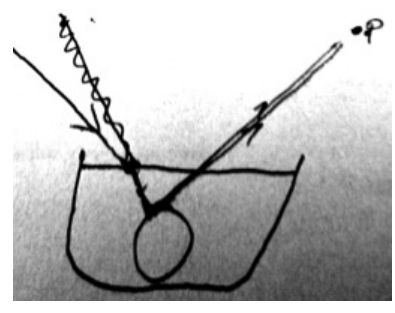

b)

Figure 5. An example of a conceptual change for understanding two optics phenomena (light reflection and light refraction) after the ALS. (a)Student \#2 used an AVM in the ALS worksheet without any evidence about a light source and image formation of the MS placed in the bowl with water. An observer's eye is marked as several $\mathrm{P}$ positions. (b) Student \#2 achieved a change, but his understanding is not still correct understanding of geometrical optics and geometry of this problem.

A few selected students' drawings included in Figure 6 show how only one ASL can contribute to be occurred conceptual change by student, especially for those students who did not understand how observer can see a metal sphere. 


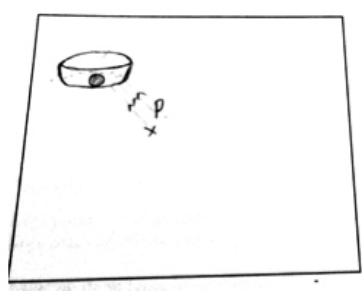

a)

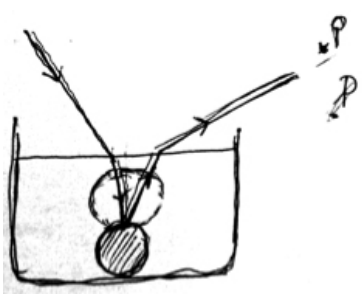

b)

Figure 6. Student \#3 showed an improved understanding of image formation and how light travels: (a) is an example of sketch without any implementation of geometrical optics knowledge, but (b) is an example showing her much improved sketch which shows the SVM understanding with all correct light travel and image formation presented almost closed as one in Figure $1 \mathrm{~b}$.

In Figure 7, Student \#4 showed also her improved understanding of image formation. She used two near rays only after light reflection at the MS point and highlighted this with the attached text (text B, Figure $7 \mathrm{~b}$ ). Looking for the completed and correct responses, there were found only six (6) of them or only six exam answers for full grading points (six).

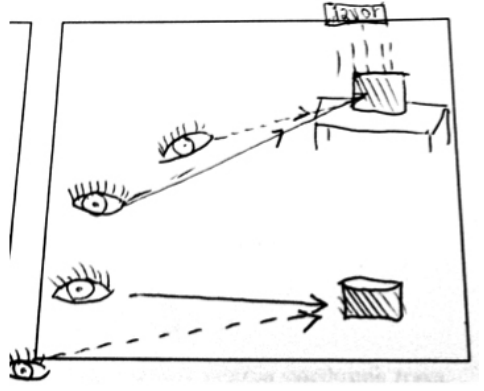

a)

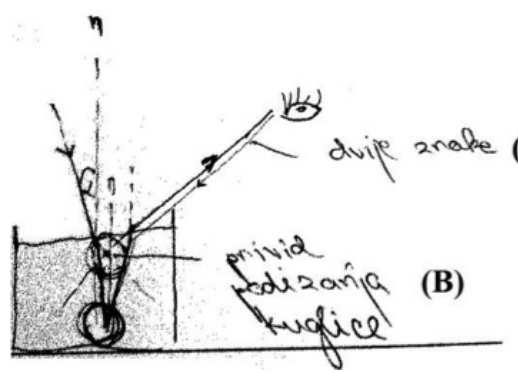

b)

Figure 7. Drawing samples by Student \#4 show the student's conceptual change from her ALS incorrect response (sketch a) to the exam solution graded as satisfactory (sketch b).

Student \#4 included (Figure 7a) a light source in her sketch (written word a source at the top of the sketch), but she presented her AVM with light rays travel from the observer's eye to the bowl and the MS as an invisible object. The same student gave her exam solution in Figure $7 \mathrm{~b}$, which almost correctly presented all elements of the SVM. In this example, it is evident that the Student \#4 has progressed. Namely, there is no longer an AVM, but she showed a better 
understanding of the SVM. There is also a textual confirmation that she has taught the necessity of drawing at least two close light rays for entering into the observer's eye. A proof of this is her text marked with the letter 'A' (Figure $7 \mathrm{~b}$ ), which, translated into English, says 'two light rays'. Student \# 4 showed that she understood the character of the MS image, if the MS was observed in the bowl with water. It is indicated in Figure $7 \mathrm{~b}$ by her text marked as letter ' $\mathrm{B}$ ' which, translated into English, says 'illusion of lifted sphere'.

\section{Student responses to the open ended questions about ALS}

The students had the opportunity to describe their feelings and thoughts about ALS realized in the amphitheatre as their usual learning environment. Their comments were collected and analysed. Almost all students (98\%) expressed their satisfaction with these learning experiences. Only two students did not declare anything about their feelings. A selection of highest positive students' response frequencies follows:

- The sequence of active learning about geometrical optics, in the way it was realized, is interesting, and I like this way of teaching and learning (69\% of students).

- Active learning is useful, interesting and helps me to better understand and learn about the phenomena of the light reflection and light refraction $(63 \%$ of students).

- I really enjoyed this class (65\% of students).

- I am definitely more interested in this method of learning than in traditional teaching ( $5 \%$ of students).

- I was effectively able to piece together the difficult problem of image formation through our active learning ( $2 \%$ of students).

Around $65 \%$ of students who were actively involved in the ALS successfully solved the exam problem at the passing level. The research results, gained after only one 90-minute active learning session, showed that around $60 \%$ of students have changed their initial alternative conceptions of vision and of image formation understanding that could be accepted as passing exam points. Some of the students repeated wrong answers, showing an insufficient understanding of what nature of the image is and how it is formed if light reflects or refracts passing through two different optical media. An important evidence of the benefit of the ALS participation is the fact that $90 \%$ of 35 the students who were not taking part in all of the ALS activities before the examination did not earn a single point for answering exam question based on the ALS. 


\section{Concluding remarks}

During the spring 2011 semester, a group of 130 science freshmen answered an exam question that covers the content of an ALS of geometrical optics carried out previously with a group of 95 students. The students showed their improved knowledge through an ALS, which possibly enabled them to achieve much better exam results. A possible additional reason for better exam results could be a 45-minute in-class presentation of correct ALS answers organized by their instructor (Z. H.) after received scores in the ALS held a week before their midterm exam. Among the 130 students who were taking the course exam, around $65 \%$ of them earned between 4 and 6 exam points for their solution based on the realized ALS geometrical optics content. Students who participated in the ALS showed better conceptual understanding of the light reflection by an opaque body (a metal sphere), light refraction passing through different optical materials, and image formation if the MS was placed in an empty bowl or in a bowl with water.

This pilot study shows prevailing positive results in the case of only one 90-minute ALS implemented in the course General Physics II. It was a way of involving a group of science freshmen in the active learning of physics, especially those who were with weak prior geometrical optics knowledge and without practice in active physics learning engagement. At the same time, it was a challenge for both students and instructor to move students from memorization to productive thinking and application of gained knowledge.

An answer to RQ1 (What were the students' possibilities and challenges in an active learning environment?) is an affirmation that there are many possibilities for introducing active physics learning at the university level, even in a large group of students (around 130-150 of students) who learn physics in an amphitheatre, which is an inadequate environment for active learning sessions. Better exam results achieved by the group of 95 ALS practitioners are found as strong students' benefits compared with exam results of previous generations of science freshmen who had also to complete the same task without any ALS in geometrical optics.

An answer to the RQ2 (What are students' conceptual changes after active learning of a geometrical optics sequence?) is the fact that students achieved a better understanding phenomena of geometrical optics, which is shown throughout their exam results. The confirmatory findings of better conceptual knowledge developed after only one ALS are based on the evidence that around $65 \%$ of the students answered the exam question for passing grades. 
Some selected results described in this paper, concerning student responses after an active learning geometrical optics sequence implemented in a large class can be used as evidence of a successful change in lecture organization by the physics instructor (Z. H). Such a change enabled obtaining initial evidence of a greater effectiveness of active learning environments when compared with traditional one. An active role of students is a better way for stronger stimulation of students' skills for productive thinking, which are needed in the application, analysis, evaluation and creation of knowledge, as the most fundamental objectives of physics teaching along cognitive process dimension.

Physics education research results indicate that physics should be taught using more interactive instructional methods. These ways of teaching require significant changes in the way faculty think about teaching and learning and corresponding changes in their teaching behaviour (Henderson, 2008, p. 179). Changing lecture design and learning environment require significant work on the part of faculty members teaching science courses or work with pre-service and in-service science teachers to be highly trained and experienced in a proper ALS.

\section{Acknowledgement}

The writing of this article was a part of Josip Sliško's sabbatical research project 'Active physics learning on line', supported by CONACyT Mexico, for the period August 2012-July 2013.

\section{Reference}

Adams, L., Kasserman, J., Yearwood, A., Perfetto, G., Bransford, J., \& Franks, J. (1988). The effects of facts versus problem-oriented acquisition. Memory and Cognition, 16, 167-75.

Beichner, J. R., Saul, M. J., Allain, J. R., Deardorff, L. D., \& Abbott, S. D. (200o). Introduction to SCALE-UP: Student-Centered Activities for Large Enrollment University Physics, presented at the Annual Meeting of the American Society for Engineering Education, Seattle, Washington, 2000. Retrieved November 122012 from http://www.ncsu.edu/per/scaleuppub.html Glashow, S. L. (1994). From Alchemy to Quarks. The study of physics as a liberal art. Pacific Grove, CA: Brooks / Cole Publishing Company.

Grabiner, R. S., \& Dunlap, J. C. (1995). Rich environments for active learning: a definition. Association for Learning Technology Journal, 3(2), 5-34.

Henderson, C. (2008). Promoting instructional change in new faculty: An evaluation of the physics and astronomy new faculty workshop. American Journal of Physics, 76(2), 179-187. 
Kaewkhong, K., Mazzolini, A., Emarat, N., \& Arayathanitkul, K. (2010). Thai high-school students' misconceptions about and models of light refraction through a planar surface. Physics Education, 45(1), 97-106.

Kulenović, E. (2006). Fizika za 8. razred osnovne škole-Šesto izdanje. Sarajevo: IP Svjetlost d.d. Zavod za udžbenike i nastavna sredstva.

Mandell, M. (1968). Physics experiment for children-Copyrighted Material. New York: Dover.

Meltzer, D. E., \& Thornton, R. K. (2012). Resource Letter ALIP-1: Active-Learning Instruction in

Physics. American Journal of Physics, 8o(6), 478-496.

Nassar, A. B. (1994). Apparent depth. The Physics Teacher, 32(9), 526-529.

Prince, M. (2004). Does Active Learning Work? A Review of the Research. Journal of Engineering Education, 93(3), 223-231.

White, R. T., \& Gunstone, R. F. (1991). Probing understanding. London: Falmer Press.

Whitehead, A. N. (1959). The aims of education. Daedalus, 88(1), 192-205.

\section{Appendix 1}

ALS Worksheet I part content and grading score.

\begin{tabular}{|c|c|c|}
\hline \multicolumn{3}{|l|}{ ALS - part I } \\
\hline Activity & Accepted answer & Grading point \\
\hline $\begin{array}{l}\text { Prediction 1: } \\
\text { Based on the Ray Model of Light, predict } \\
\text { the positions that you can see the } \\
\text { metal sphere located at the bottom of an } \\
\text { opaque bowl, filled with air. Mark the posi- } \\
\text { tion of the eye of an observer in a point P } \\
\text { (or sketch the eye in a proper position). }\end{array}$ & $\begin{array}{l}\text { Scientific vision model used: } \\
\text { Drawing } 1 \text { is a set of at least } \\
\text { two light rays that travel from a } \\
\text { light source to the metal sphere, } \\
\text { reflect off it and reach the ob- } \\
\text { server's eye or position P. }\end{array}$ & 1 \\
\hline $\begin{array}{l}\text { Observing 1: } \\
\text { Student observes the metal sphere in the } \\
\text { bowl and tries to evaluate his/her own } \\
\text { prediction. Student is asked to confirm } \\
\text { her/his prediction with observing results. }\end{array}$ & $\begin{array}{l}\text { Student confirms the own } \\
\text { prediction and own result of } \\
\text { observing in the experiment. }\end{array}$ & 1 \\
\hline $\begin{array}{l}\text { Explanation 1: } \\
\text { If there is a difference between the } \\
\text { predicted and observed position of } \\
\text { observer's eye, you need to make a better } \\
\text { distribution of eye position that MS is vis- } \\
\text { ible. Use the Ray Model of Light. }\end{array}$ & $\begin{array}{l}\text { Using the scientific vision model } \\
\text { of explanation for a new and } \\
\text { correct drawing. }\end{array}$ & 1 \\
\hline
\end{tabular}




\section{Appendix 2}

ALS Worksheet II part content and grading score.

\begin{tabular}{l} 
ALS - part II \\
\hline Activity \\
\hline Prediction 2: \\
Metal sphere (MS) is at the same place in \\
the bowl. If the bowl is filled with water, \\
predict what will happen if you observe \\
the MS from the previous place of the \\
invisible MS for you: \\
(a) The MS will be invisible. \\
(b) The MS visible part will be lower than $\quad$ Correct answer is (d). \\
in the empty bowl. \\
(c) The MS visible part will be the same as \\
in the empty bowl. \\
(d) The MS visible part will be higher than \\
in the empty bowl. \\
(e) It is not possible to predict the effect \\
for MS visibility placed in the bowl \\
with water.
\end{tabular}

Scientific vision model used: Drawing 2 is presented by at least of two light rays that travel from the light source to the water surface and refracts in water changing the path. After reaching the MS, the light rays are reflected on the metal sphere point and then refracted again leaving water, and travel to the observer's eye in position $\mathrm{P}$.

A seen MS is not its real image (new image is a case of the MS lifted in comparison of its previous positions in the bowl).

Observing 2:

Perform the experiment.

Question 1:

If your prediction 2 was correct you need to mark which one:
(a) (b)
(b) (c)
(d) $(e)$

Accurate prediction.

Question 2:

If your prediction 2 was wrong you need to mark which one:
(a) (b)
(c)
(d) (e) 


\section{Biographical note}

Zalkida Hadžibegović (BSc in Physics, MSc in History and Philosophy of Science, PhD in Physics) teaches courses on General Physics, Astronomy, and Philosophy and History of Science at University of Sarajevo, Bosnia and Herzegovina. She established in 2009 the first science education research group (Sarajevo Chemistry and Physics Education Research Group), which conducts research on integrated Chemistry, Physics, Mathematics, History and Philosophy of Science knowledge, and has focused on active learning approach. Her research interests include the applications of history and philosophy of science in science education, students' scientific literacy, science knowledge integration, and creativity at university and high school level especially for talented students.

JosıP SLIŠko (BSc in physics, MSc in philosophy of physics, $\mathrm{PhD}$ in philosophical sciences) teaches courses on physics and mathematics education at Facultad de Ciencias Físico Matemáticas of the Benemérita Universidad Autónoma de Puebla. His research interests include students' explanatory and predictive models of physical phenomena, students' strategies for solving untraditional physics and mathematics problems, presentation of knowledge in textbooks and the design of active learning sequences that promote cognitive, metacognitive and emotional development of students. Josip Sliško is the author or co-author of 80 journal articles and 12 physics textbooks. Since 1993, every last week in May, he is the president of the committee that organizes an international workshop called New Trends in Physics Teaching. 